\title{
POLITIK DAN BIROKRASI DI NEGARA BAGIAN SABAH MALAYSIA (Studi Kasus Intervensi Pejabat Politik Terhadap Pejabat Birokrasi)
}

\begin{abstract}
Azhari $^{1}$
Abstract

This research make into Sabah as standard of comparison region (benchmark) with aim to study why in Sabah especially and Malaysia of commonly public bureaucracy difficult intervention by politic Official, be based elaboration of mutation cases to power teacher from Kelantan to Sabah where could not conducted by of the same level ministry phased federation, because this action spurred existence importance politic party UMNO authorizing phased Federal but could not authorize in Kelantan and Sabah, Mazlan bin Ali (1998). In efforts organize study this research, researcher based self of politic system theory as Grand theory, and so authority distribution theory as middle range theory and bureaucracy relation arrangement theory as operational theory. Method were used in conduct effort look for data and its analysis, this research take research method of qualitative descriptive, with hope could description and explain found fact in square be clearly and most systematic. Pass through this research, founded that relation of politic Official and bureaucracy in Indonesia go on in Assendency Executive model with new variant that is Assendency Executive Personal. While Sabah follow relation pattern that inclined Bureaucratic Sublation.
\end{abstract}

Keywords: Politics, bureaucracy, governance systems, and government

\begin{abstract}
Abstrak
Penelitian ini membuat Sabah sebagai standar wilayah pembanding (benchmark) dengan tujuan untuk mempelajari mengapa di Sabah dan Malaysia khususnya intervensi birokrasi publik yang umumnya sulit oleh Pejabat politik, menjadi elaborasi berbasis kasus mutasi guru daya dari Kelantan ke Sabah di mana tidak bisa dilakukan oleh kementerian tingkat yang sama berbentuk federasi, karena

\footnotetext{
${ }^{1}$ Penulis adalah Staf Pengajar pada Sekolah Tinggi Keguruan dan Ilmu Pendidikan Sembilan Belas November Kolaka Sulawesi Tenggara, dan juga mengajar di Program Pascasarjana Universitas Wijaya Putera Surabaya. Alamat kontak: achidsti_sayfa@yahoo.com
} 
tindakan ini mendorong adanya kepentingan politik partai UMNO otorisasi berbentuk federal tetapi tidak bisa mengotorisasi di Kelantan dan Sabah. Dalam upaya mengatur studi penelitian ini, peneliti berbasis teori sistem politik sebagai Grand Theory, sehingga otoritas teori distribusi sebagai teori kisaran menengah dan birokrasi teori hubungan pengaturan sebagaimana teori operasional. Metode yang digunakan dalam melakukan upaya untuk melihat data dan analisis, penelitian ini mengambil metode penelitian deskriptif kualitatif, dengan harapan bisa mendeskripsikan dan menjelaskan fakta yang ditemukan di lapangan secara jelas dan sangat sistematis. Melalui penelitian ini, ditemukan bahwa hubungan Resmi politik dan birokrasi di Indonesia melanjutkan model Assendency Executive dengan varian baru yaitu Executive Assendency Personal. Sementara Sabah mengikuti pola hubungan yang cenderung Bureaucratic Sublation.

Kata kunci: Politik, birokrasi, sistem pemerintahan, pemerintah

\section{Sistem Politik Malaysia}

Malaysia sejak kemerdekaannya mengamalkan sistem pemerintahan kerajaan dengan model pemerintahan kerajaan konstitusional atau di Malaysia dikenal dengan istilah raja yang berperlembagaan. Kedudukan raja sebagaimana termaktub dalam Konstitusi Malaysia merupakan kepala negara yang tidak melaksanakan pemerintahan.

Hak-hak sebagaimana yang tertuang dalam konstitusi tersebut dilaksanakan dengan usulan perdana menteri yang berkuasa, selaku kepala pemerintahan. Secara umum Raja Malaysia hanyalah lambang yang tidak memiliki kekuatan politik nyata dalam penyelenggaraan kebijakan pemerintahan di Malaysia. Alat kelengkapan Kerajaan Malaysia terdiri atas:

\section{Badan Perundangan}

Badan perundangan (Parlemen Malaysia) mengandung tiga komponen utama yaitu:

i. Yang di-Pertuan Agong,

ii. Dewan Negara (Senat), dan

iii. Dewan Rakyat (House of Representative).

Ketiga komponen tersebut di atas memiliki kewenangan dalam membuat Uundang-undang di Kerajaan Malaysia proses pembuatannya diawali dari 
usulan/rancangan undang-undang yang berasal dari eksekutif (kabinet) usulan kemudian dibahas oleh Dewan Rakyat setelah tahapan pembahasan pada Dewan Rakyat selesai, maka rancangan tersebut diserahkan kepada Dewan Negara (Senat) untuk dibahas selanjutnya. Rancangan yang telah disetujui oleh Senat kemudian diserahkan kepada Yang di-Pertuan Agong untuk mendapatkan pengesahan.

\section{Dewan Rakyat}

Keanggotaan Dewan Rakyat dipilih melalui pemilihan umum dengan masa jabatan 4 tahun jumlah anggota Dewan Rakyat 222 orang. $^{2}$ Keanggotaan Dewan Rakyat merupakan representasi partai politik yang mengikuti seleksi melalui pemilihan umum. Setiap anggota Dewan Rakyat memiliki masa kerja selama empat tahun, tetapi Perdana Menteri dapat mengusulkan kepada Raja agar pemilihan umum segera diadakan. Sebagai negara yang menganut bentuk federalisme, pembentukan partai di Malaysia lebih muda dan partai lokal disetiap negara bagian dapat berdiri. Kemudian partai tersebut akan membangun koalisi dengan dengan partai yang ada pada tingkat nasional. Partai-partai besar di Malaysia antara lain Partai Kebangsaan Melayu, Partai Islam Se-Malaysia (PAS), Persatuan Cina Tanah Melayu (MCA), Kongres India Tanah Melayu (MIC), Partai Negara, dan Partai Keadilan. Koalisi partai di Malaysia terdiri atas koalisi Barisan Nasional yang dipimpin oleh UMNO, dan Koalisi barisan alternatif yang terdiri atas partai Keadilan, PAS, Partai DAP yang koalisinya dipimpin oleh Anwar Ibrahim.

\section{Badan Pemerintahan (Eksekutif)}

Komponen dari badan pemerintahan atau eksekutif Kerajaan Malaysia adalah Yang di-Pertuan Agong sebagai kepala negara, memiliki kekuasaan eksekutif; kekuasaan tersebut kemudian dijalankan oleh Kabinet. Sesuai dengan Konstitusi Federal, Yang di-Pertuan Agong dapat mengambil keputusan tanpa pertimbangan kabinet atau berdasarkan kebijakannya sendiri dalam tiga perkara, yaitu Melantik Perdana Menteri, tidak menyetujui permintaan untuk membubarkan Parlemen dari Perdana Menteri, dan meminta supaya diadakan musyawarah raja-raja untuk membahas tentang kedudukan

2 Tanpa Pengarang, "Malaysia Kita", (Kuala Lumpur: Institut Tabiran Awam Negara (INTAN), 1994), hal, 545. 
keistimewaan raja-raja atau hal-hal lain yang menyangkut agama Islam dan adat istiadat. Yang di-Pertuan Agong dan para raja Persekutuan merupakan pemimpin tertinggi agama Islam di Negara Malaysia demikian pula halnya para raja dan Yang di-Pertuan Negeri merupakan pemimpin tertinggi agama Islam dan adat istiadat di negerinya. Dalam pelaksanaanya badan eksekutif dipimpin oleh seorang perdana menteri, yang dipilih dari dan oleh anggota Dewan Rakyat, berdasarkan suara partai yang duduk di parlemen.

\section{Badan Kehakiman}

Kekuasaan kehakiman di Malaysia diatur dalam pasal 121 (1) Undangundang Federal. Kuasa kehakiman tertinggi di negara ini terletak pada Mahkamah Agung. Malaysia juga memiliki dua Mahkamah Tinggi Persekutuan yaitu Mahkamah Tinggi di Malaya, dan Mahkamah Tinggi di Borneo. Setelah Mahkamah tersebut di semenanjung Malaya terdapat 4 mahkamah rendah yang terdiri atas:

i. Mahkamah Sesyen: yaitu Mahkamah yang tertinggi di negeri/daerah, walaupun berada di bawah Mahkamah Tinggi Persekutuan;

ii. Mahkamah Majistret: Mahkamah ini dipimpin oleh dua orang Majistret (hakim) yaitu hakim kelas pertama dan hakim kelas kedua;

iii. Mahkamah Juvenil: dilaksanakan oleh Majistret kelas pertama yang dapat memutuskan semua kasus kecuali yang menjatuhkan hukuman mati;

iv. Mahkamah Penghulu: dilaksanakan oleh seorang Kepala Kampung atau Mukim, kuasa Mahkamah ini sangat lemah, sebab dia hanya dapat menyelesaikan kasus-kasus secara informal, dan Mahkamah ini hanya boleh mengadili yang tidak lebih dari $\$ 50$, serta denda tidak lebih dari $\$ 25$.

\section{Negara Bagian Sabah}

Negara Bagian Sabah Malaysia Timur terletak di sebelah barat Pulau Kalimantan, dengan luas wilayah $74.500 \mathrm{~km}^{2}$ (29.388 mil), dengan garis pantai sepanjang $74.500 \mathrm{Km}^{2}$. Iklim di Sabah berkisar di antara $74^{\prime} \mathrm{F}$ (23')-90’ F (33' C). Jumlah penduduk Sabah menurut sensus tahun 2000 terdapat 2.449.389 juta jiwa, yang terdiri atas 30 ras dengan 80 dialek bahasa. Suku yang terbesar adalah suku Kadazan, Bajau, dan Murut. Karena letaknya yang berseberangan dan suku aslinya yang serumpun dengan suku Dayak di Kalimantan, maka dalam bahasa sehari-hari 
masyarakat Indonesia khususnya Kalimantan menyebut Sabah dan Serawak sebagai Kalimantan Utara.

Setelah Sabah mencapai kemerdekaan dan resmi bergabung dengan Federasi Malaysia, maka struktur jabatan politik dan pemerintahan yang ada tetap di pertahankan, dengan beberapa penyesuaian. Adapun kelembagaan dan struktur pemerintahan Negara Bagian Sabah Malaysia setelah kemerdekaan hingga saat ini adalah sebagai berikut:

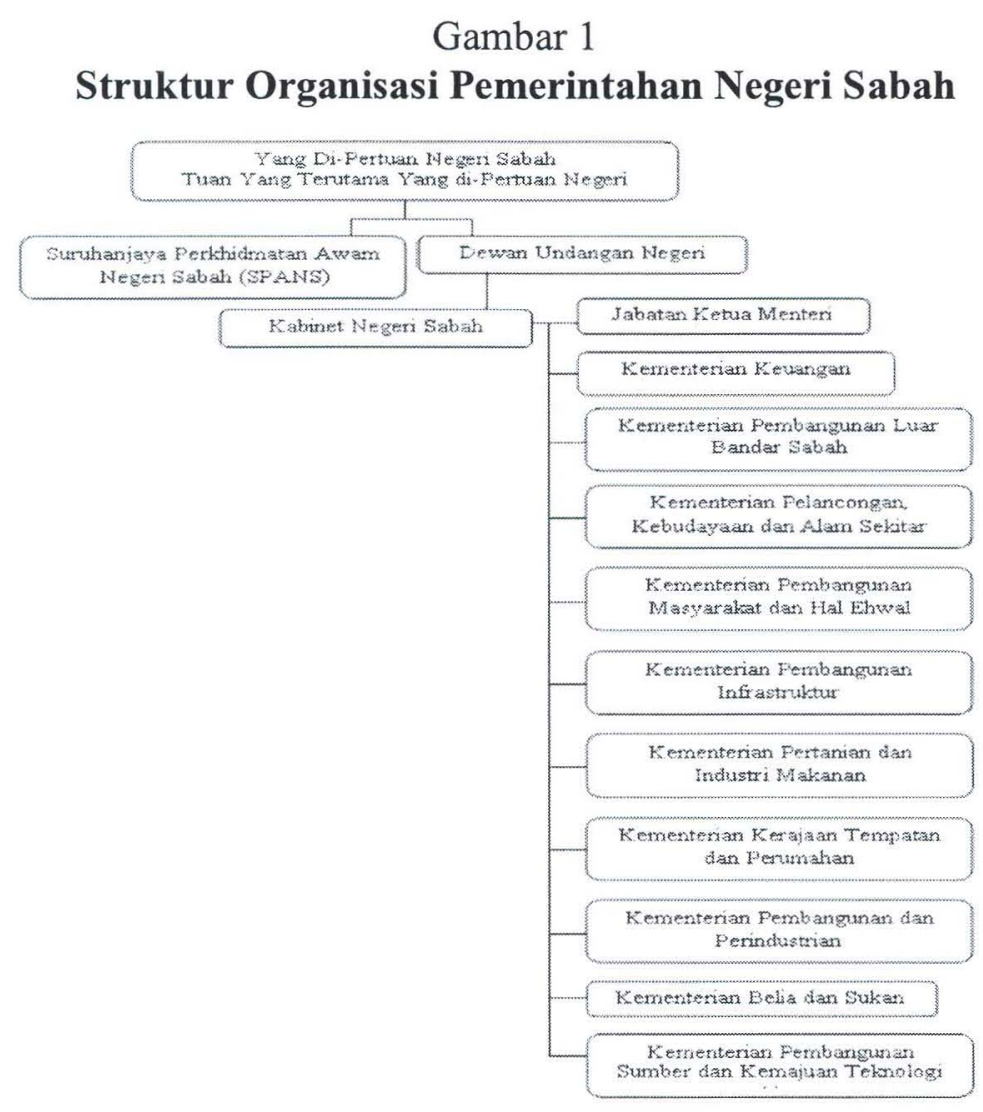

\section{Tuan yang Terutama Yang di-Pertuan Negeri Sabah}

Yang di-Pertuan Negeri merupakan pemimpin tertinggi Negeri Sabah, sementara yang menjalankan kekuasaan pemerintahan adalah kabinet yang dipimpin oleh perdana menteri (ketua menteri, untuk Sabah). Di Negara Malaysia, raja merupakan simbol kerajaan atau kepala negara, tetapi pelaksana kebijakan pemerintahan adalah perdana menteri, demikian pula halnya di 
sembilan negara bagian di Malaysia (Kelantan, Trengganu, Perlis, Negeri Sembilan, Pahang, Kedah, Pulau Pinang, Selangor, dan Perak) yang tetap berstatus kerajaan dan menempatkan raja sebagai pemimpin tertinggi di negeri (negara bagian) tersebut.

Tetapi karena Sabah termasuk satu dari empat negara bagian (Sabah, Serawak, Pulau Pinang dan Melaka) yang tidak memiliki raja, maka untuk menggantikan posisi raja diangkatlah Ketua Negeri yang bergelar Tuan Yang Terutama Yang di-Pertuan Negeri. Karena statusnya yang bukan raja dan pengangkatannya atas usul ketua menteri yang kemudian dilantik oleh Duli Yang Maha Mulia Yang di-Pertuan Agung (raja) Malaysia untuk masa jabatan empat tahun, maka dengan sendirinya kekuasaan Ketua Negeri sangatlah terbatas. Sesuai peraturan Perlembagaan Negeri Sabah, Ketua Negeri dalam mengambil keputusan harus memperhatikan nasehat dari Ketua Menteri dan Kabinet kecuali dalam hal:

1) Pelantikan Ketua Menteri;

2) Penangguhan memperkenankan permohonan untuk membubarkan Dewan Undangan Negeri. ${ }^{3}$

Ketua Negeri bertempat tinggal di Istana Kerajaan Negeri Sabah, dan sebagaimana lazimnya maka di Istana terdapat Kepala Rumah Tangga Istana, dan di Sabah, pelaksana tugas-tugas di istana dipimpin oleh seorang yang bergelar "Setiausaha Sulit" yang memimpin 43 orang karyawan keadaan sesuai dalam buku Panduan Perkhidmatan Awam Negeri Sabah Jilid I. ${ }^{4}$

\section{Dewan Undangan Negeri (DUN) Sabah}

Dewan Undangan Negeri (DUN), merupakan pemegang kekuasaan legislatif di Negara Bagian Sabah Malaysia, Dewan Undangan Negeri Sabah memiliki kelengkapan yang terdiri atas pimpinan atau speaker dan timbalan speaker serta 60 orang anggota yang dipilih melalui pemilihan umum yang diadakan lima tahun sekali. Pemilihan umum di Sabah dilaksanakan sejak tahun 1967 atau empat tahun setelah kemerdekaannya. Dewan Undangan Negeri Sabah memiliki kewenangan sebagai lembaga yang memiliki hak

\footnotetext{
${ }^{3}$ Maria Othman Lee, "Kementerian dan Jabatan", (Kinabalu: tanpa penerbit, 1992), hal. 95.

${ }^{4}$ Maria Othman Lee, "Panduan Perkhidmatan Awam Negeri Sabah Jilid I", (Kinabalu: tanpa penerbit, 1992), hal. 95.
} 
legislatif untuk membuat keputusan yang menyangkut kewenangan yang dimiliki oleh Negara Bagian Sabah berdasarkan perjanjian yang diatur dalam konstitusi atau perlembagaan persekutuan. Selain kewenangan negeri tersebut, DUN juga dapat membuat secara bersama-sama dengan parlemen Malaysia menyangkut aturan atau kesepakatan menyangkut kewenangan bersama yang dimiliki secara joint service antara pemerintah pusat (persekutuan) dengan pemerintah Negara Bagian Sabah.

Sesuai Konstitusi Sabah, calon anggota DUN dibolehkan untuk mengikuti pemilihan sebagai anggota Dewan Undangan Negeri dari jalur perseorangan. Tetapi secara umum, anggota Dewan Undangan Negeri Sabah berasal dari partai politik. Partai politik juga tidak selamanya partai yang ada pada level nasional atau partai yang dominan di semenanjung Malaysia dapat populer juga di Sabah, sebab, sebagai negara yang menganut federalisme, Malaysia memungkinkan dibentuknya partai-partai politik di masing-masing negara bagian berdasarkan UUD masing negara bagian tersebut. Untuk lebih jelasnya partai yang menang dan memipin pemerintahan di Negara Bagian Sabah Sejak merdeka adalah sebagai berikut:

Tabel 1.

\section{Partai yang Memerintah di Sabah Sejak Tahun 1963}

\begin{tabular}{|l|l|}
\hline Tahun 1963-1967 & Aliansi Partai (USNO, UPKO, SIC) \\
\hline Tahun 1967-1975 & Koalisi USNO, SCA \\
\hline \multirow{2}{*}{ 13 April 1976- Februari 1981 } & Berjaya (pemegang Pemerintahan) \\
\cline { 2 - 2 } & USNO dan SCCP (oposisi) \\
\hline \multirow{2}{*}{28 Maret 1981- 20 April 1985 } & BERJAYA \\
\cline { 2 - 2 } & USNO (oposisi) \\
\hline 21 April 1985 - 26 Februari 1986 & Partai bersatu Sabah (PBS) \\
\hline & Berjaya dan USNO (oposisi) \\
\hline 06 Mei 1986-16 Juli 1990 & Partai Bersatu Sabah (PBS) \\
\hline & USNO (oposisi) \\
\hline 18 Februari 1990 - 17 Februari 1994 & Partai Bersatu Sabah (PBS) \\
\hline & USNO (oposisi) \\
\hline 21 Februari 1994- 16 Maret 1994 & Partai Bersatu sabah (PBS) \\
\hline & Barisan Nasional (oposisi) \\
\hline 17 Maret 1994- 13 Maret 1999 & Barisan Nasional \\
\hline & Partai Bersatu Sabah (oposisi) \\
\hline 14 Maret 1999- Sekarang & Barisan Nasional \\
\hline
\end{tabular}


Sumber: Website Resmi Sabah, diakses tanggal 3 Maret 2008

\section{Kabinet Negeri Sabah}

Malaysia, mengatur bahwa pemegang kuasa bagi suatu negeri adalah raja, bagi yang ber-raja dan bagi negara bagian yang tidak ber-raja seperti Sabah, pemegang kuasa tertinggi adalah ketua negeri, pelaksana dari kuasa tersebut adalah kabinet negeri (musyawarah kabinet). Dengan demikian, maka kabinet juga merupakan pengambil kebijakan tertinggi atas pelaksanaan pemerintahan umum di Sabah. Kabinet negeri terdiri atas sebelas orang menteri, yang dipimpin oleh seorang ketua menteri dan timbalannya (wakil). Ketua menteri berasal dari anggota Dewan Undangan Negeri, tentunya dari partai mayoritas kemudian membentuk kabinet yang juga berasal dari anggota Dewan Undangan Negeri. Kabinet yang dipimpin oleh ketua menteri dapat mengajukan usulan untuk membubarkan Dewan Undangan Negeri kepada Ketua Negeri Sabah.

Saat ini di negara bagian Sabah terdapat sebelas kementerian, termasuk di dalamnya ketua menteri. Setiap kementerian mempimpin suatu jabatan sebagai pelaksana (unsur lini) dari suatu kementerian. Selain memimpin beberapa jabatan, setiap kementerian juga memiliki Badan Berkanun (BUMD) yang ada di bawah kementeriannya. Setiap kementerian memiliki organisasi tersendiri, tetapi umumnya memiliki organisasi yang minimal, terutama apabila dilihat dari jumlah jabatan struktural dan pegawai.

\section{Suruhanjaya Perkhidmatan Awam Negeri}

Lembaga ini adalah suatu komisi pemerintahan yang anggotanya diangkat dari kalangan orang-orang profesional non-partisan, dan dilantik oleh Yang diPertuan Negeri, atas saran ketua menteri. Tugas yang dijalankan oleh Suruhanjaya Perkhidmatan Awam Negeri adalah melantik, menaikkan pangkat, mengesahkan jawatan, memberi perlantikan secara pertukaran jawatan, melantik semula pensarah yang masih dikehendaki perkhidmatannya, meresapkan kaki tangan kerajaan kejawatan tetap dan berpencen, melanjutkan tempo percobaan, memendekkan kontrak, menamatkan perkhidmatan dan mengambil tindakan tata tertib terhadap semua kaki tangan 
dalam Perkhidmatan Awam negeri ${ }^{5}$ (Lee, 1992:105). Suruhanjaya Perkhidmatan Awan Negeri memiliki dua kelengkapan kelembagaan yaitu:

a. Suruhanjaya sendiri terdiri atas seorang pengerusi (ketua), seorang timbalan pengerusi (wakil ketua), dan tujuh orang ahli (anggota) lembaga Suruhanjaya yang dilantik oleh T.Y.T. Yang di-Pertuan Negeri setelah berunding dengan Ketua Menteri. Mereka diamanahkan untuk melaksanakan fungsi dan tanggungjawab Suruhanjaya dalam semua aspek-aspek yang berkaitan dengan Suruhanjaya;

b. Unit yang satu lagi terdiri dari kaki tangan kerajaan (pegawai) yang diketuai oleh Suruhanjaya Perkhidmatan Awam dan unit ini bertindak sebagai urus setia (semacam sekretaris) bagi menjalankan fungsi-fungsi Suruhanjaya. ${ }^{6}$

Tidak semua Negara Bagian di Malaysia memiliki Suruhanjaya sendiri sehingga tugas-tugas yang seharusnya dilakukan oleh Suruhanjaya negeri diambil alih oleh Suruhanjaya persekutuan melalui cabangnya yang ada di negara bagian yang bersangkutan. Suruhanjaya Perkhidmatan Awam Negeri memiliki kuasa yang besar atas pengangkatan dan pengaturan kepegawaian, sehingga kepegawaian dapat ter-manage dengan baik, dan kualitas yang dimiliki oleh setiap pegawai memang sesuai dengan golongan atau gred yang disandangnya.

\section{Setiausaha Kerajaan Negeri}

Apabila ketua negeri, Dewan Undangan Negeri, kabinet dan anggotanya, serta Suruhanjaya Perkhidmatan Awam Negeri, merupakan jabatan politik/ bukan jabatan karier, maka jabatan birokrasi dikoordinasikan di bawah jabatan Setiausaha Kerajaan Negeri, yang juga menjadi setiausaha pada jabatan Ketua Menteri. Apabila kita bawa dalam struktur pemerintahan daerah di Indonesia, maka Setiausaha Kerajaan Negeri yang bergelar urusetia, dapat disepadankan dengan sekretaris daerah, akan tetapi dari segi kewenangan dan netralitas dalam melaksanakan fungsinya, agaknya setiausaha lebih independen dibandingkan dengan sekda. Urusetia dengan sendirinya adalah pejabat birokrasi paling kanan atau paling senior dalam pemerintahan. Setiausaha

\footnotetext{
${ }^{5}$ Ibid., hal. 105,

${ }^{6}$ Ibid., hal 78 .
} 
Kerajaan Negeri dibantu oleh tiga orang timbalan (wakil) setiausaha, dan ketiga timbalan setiausaha tersebut membawahi bahagian dan jabatan serta unit yang ada dalam jabatan ketua menteri. Untuk lebih jelasnya berikut gambar struktur organisasi Setiausaha Kerajaan Negeri.

\section{Pejabat Daerah}

Secara umum, Malaysia membagi wilayahnya atas enam tingkatan yaitu: (1) Pemerintah Pusat; (2) Pemerintah Negara Bagian; (3) Majelis Perbandaran/Kerajaan Tempatan (Pemerintah Kota); (4) Pejabat Daerah; (5) Mukim; dan (6) Kampung.

Negara Bagian Sabah memiliki sedikit perbedaan dengan negara bagian lainnya dalam penyusunan organisasi pemerintahan daerahnya, sebab, di Sabah setelah pemerintahan kerajaan negeri (negara bagian), maka pengaturan wilayah selanjutnya langsung kepada pejabat daerah. Daerah kemudian dibagi dalam wilayah anak negeri, selanjutnya wilayah anak negeri dibagi pula dalam wilayah kampung. Pejabat daerah atau ketua daerah bertanggungjawab dalam melaksanakan adat istiadat negeri di daerah tersebut. Pegawai daerah dibantu oleh ketua anak negeri, dan wakil ketua anak negeri serta kepala kampung dalam mengatur wilayah daerah tersebut. Secara umum, penyusunan wilayah di Sabah mengikuti apa yang telah di laksanakan oleh pemerintah Kerajaan Inggris, yang diubah hanya keberadaan residensi yang dihilangkan.

\section{Birokrasi (Kepegawaian)}

Dari segi manajemen kepegawaian, Malaysia menerapkan manajemen yang tersentralistik, dan kaum birokrasi merupakan golongan yang memiliki prestise tersendiri dalam masyarakat. Pegawai hanya akan bertanggungjawab kepada atasannya dalam pemerintahan, dan bersikap masa bodoh dengan politik.

Selain itu tahapan untuk menjadi pegawai negeri juga sangat berbelit: diawali dari penerimaan, percobaan selama 2 tahun, selanjutnya pengangkatan dalam jawatan dan seterusnya pengangkatan dalam jawatan berpencen. Seorang karyawan yang diterima bekerja, akan menjalani masa percobaan selama 2 tahun, dan apabila dipandang baik akan diangkat dalam jawatan tetap, setelah dipandang baik oleh komisi penilai maka pegawai yang bersangkutan akan dimasukkan sebagai pegawai yang menerima hak pencen (pensiun). Sabah juga memberi istilah pegawai sebagai jawatan, tetapi jawatan 
lebih mengarah pada jenis pekerjaan yang dijalankan oleh pegawai yang bersangkutan. Sehingga dalam struktur organisasi pemerintahan Sabah yang lengkap, di dalamnya akan termasuk sopir dan tukang parkir atau pengepel ruangan juga memiliki kotak tersendiri dalam struktur organisasi.

Golongan pegawai dibagi ke dalam kumpulan yang dimulai dalam kumpulan khas atau tertinggi, disebut kumpulan A, sampai yang terendah adalah kumpulan $\mathrm{D}$, pegawai juga telah dibagi dalam bidang tugas dan spesialisasinya masing-masing.

\section{Kelengkapan Pemerintahan Kota/Penguasa Tempatan (Bandar)}

Keberadaan penguasa tempatan di Malaysia telah ada sejak jaman Kerajaan Melayu, walaupun secara umum (modern) kerajaan tempatan dilaksanakan oleh penguasa British di Pulau Pinang pada tahun 1801. Sebagaimana yang ada dituliskan dalam buku," "Perkembangan Kerajaan Tempatan bermula dengan penubuhan Jawatan Kuasa Taksiran (comitee of assessors) di Pulau Pinang pada tahun 1081."

Sejak tahun 1965, Malaysia telah mengadakan upaya penyusunan kembali struktur kerajaan tempatan, dan akta tersebut membagi penguasa tempatan pada dua jenis saja, yaitu Majelis Perbandaran dan Majelis Daerah. Sedangkan jumlah penguasa tempatan di Malaysia dikurangkan dari 373 menjadi 91 buah. Sampai pada tahun 1986 di Malaysia hanya terdapat 16 Majelis Perbandaran, termasuk Dewan Bandaraya, dan 75 Majelis Daerah.

Saat ini, di Negara Bagian Sabah terdapat 17 Majelis Daerah dan 2 Majelis Perbandaran, dan satu lembaga bandaran yang ada di bawah kewenangan kementerian kerajaan tempatan. Sedangkan Kota Kinabalu (Majelis Perbandaran kinabalu) berada di bawah pengawasan jabatan ketua menteri. Dengan demikian di seluruh negara nagian sabah terdapat 221 buah penguasa tempatan/pemerintah kota.

Jumlah keseluruhan pegawai yang bekerja pada institusi Penguasa Tempatan di Negara Bagian Sabah Malaysia adalah 4192 orang (1995). Dari jumlah tersebut menurut analisa data yang dimuat dalam Profil Perkhidmatan Sabah, ${ }^{8}$ yang diperlukan adalah 4.871 orang atau $16 \%$ dari keseluruhan

\footnotetext{
7 "Malaysia Kita", Op. Cit., hal. 649.

${ }^{8}$ Tanpa Pengarang, "Buku Profil Perkhidmatan Awam Negeri Sabah, Bagian Pembangunan dan Organisasi Jabatan Perkhidmatan Awam Negeri”, (Kinabalu: tanpa penerbit, 1995), hal. 8.
} 
jawatan (pegawai) yang ada di Negara Bagian Sabah. Tetapi yang terpenuhi kurang 679 orang atau kurang 2\% dari jumlah yang seharusnya. Dan dari jumlah tersebut, jawatan (pegawai) yang telah menjadi pegawai tetap dan berpencen (menerima hak pensiun) adalah 4.711 jawatan/orang, sedangkan sisanya 160 jawatan/orang adalah jawatan/pegawai yang belum memiliki hak untuk menerima pensiun. Selain itu dari jumlah keseluruhan anggota/pegawai yang ada tersebut di atas, pegawai tetap berjumlah 3.115 orang/pegawai, 913 orang berstatus pegawai sementara, dan 28 orang berstatus kontrak, serta 136 orang lainnya termasuk dalam kategori lain-lain. Terdapat keunikan tersendiri dalam pengaturan kepegawaian antara Indonesia dan Malaysia, dan peneliti akan menjelaskannya pada sub pokok bahasan selanjutnya.

\section{Hubungan Pejabat Politik Dan Pejabat Birokrasi}

\section{Profil Birokrasi}

Birokrasi di Malaysia, khususnya di Negara Bagian Sabah Malaysia, menganut budaya birokrasi kerajaan Inggris yang menempatkan Pamong Praja sebagai institusi yang berkelas dan memiliki prestise yang tinggi di masyarakat. ${ }^{9}$ Dengan demikian, birokrasi dibentuk dalam organisasi yang spesialis dan profesional. Sehingga sampai saat ini pengaturan kepegawaian di Negara Bagian Sabah, menempatkan kode spesialisasi kepegawaian seseorang pada bagian namanya. Misalnya seorang pegawai yang bekerja pada sektor pemerintahan umum dan memiliki kemampuan administrasi pemerintahan, maka yang bersangkutan diberi kode "N". Selanjutnya angka yang ada dibelakang kode tersebut menunjukan golongan kepegawaian seorang birokrat, semakin besar angka yang mengikutinya akan semakin tinggi golongan kepegawaian yang bersangkutan dalam spesialisasi adminitrasi pemerintahan.

Untuk mengisi suatu jawatan (kekosongan pegawai tertentu), maka pejabat yang memiliki kekurangan staff tersebut harus melapor kepada Suruhanjaya, dan Suruhanjaya wajib mengiklankannya minimal pada satu surat kabar (pasal 12, Lantikan dan Kenaikan Pangkat). Di Sabah, pegawai negeri menempati suatu posisi yang disebut jawatan, sehingga sulit untuk diklasifikasikan apakah yang bersangkutan struktur atau bukan sebab struktur organisasinya terpola sedemikian rupa secara profesional dan dikendalikan sehingga jarang ditemukan pegawai dengan golongan tinggi tetapi tidak memiliki jabatan.

\footnotetext{
${ }^{9}$ Lihat Bedlington, dalam Mas'oed, 1997: 243.
} 
Menurut narasumber, Said Hinayat, bahwa pegawai non-job bisa saja terjadi, tetapi letak kesalahannya harus jelas sesuai peraturan perundangan. Apabila menteri atau pengarah memberikan hukuman tanpa sesuai aturan perundangan, maka pegawai yang merasa dirugikan dapat mengajukan keberatan kepada pengadilan. Apabila pegawai yang bersangkutan menang dalam pengadilan maka pemerintah wajib mengembalikannya dalam posisi semula serta memberikan semua hak-hak yang melekat pada kedudukan pegawai tersebut sebelumnya walaupun dalam masa non-job tersebut. Selain itu, menurut narasumber saya tersebut, seorang pegawai yang tidak diberi jabatan atau kedudukan tetap harus menikmati fasilitas pemerintah berupa gaji, tunjangan perumahan, kendaraan dan lain-lain yang memang harus diperoleh oleh pegawai yang bersangkutan berdasarkan golongan kepegawaiannya.

Kondisi yang demikian memang akan membuat sulit berpikir bagi para pejabat politik yang hendak mempermainkan karier pejabat birokrasi. Sebab manajemen kepegawaian Malaysia telah mengatur sedemikian rupa bahwa kenaikan pangkat seorang pegawai pemerintah dilakukan dengan standar yang meryt system, demikian juga penerimaannya sehingga tidak muda untuk naik pangkat juga tidak muda untuk merekrut pegawai. Manajemen kepegawaian diatur sedemikian rupa dengan aturan yang ketat sejak pertama diangkat sebagai pegawai birokrasi sudah ditetapkan bahwa untuk ijazah SMA hanya bisa pensiun sampai pada gred tertentu, demikian pula S-1 dan S-2. Semuanya sudah terpola sejak awal sehingga tidak ada istilah diangkat jadi pegawai golongan SMA tetapi sekolah terus asal mendapatkan ijazah sampai S-2 agar menduduki posisi puncak di birokrasi.

Malaysia telah mengatur hanya tamatan yang diangkat dengan kualifikasi master saja yang bisa menempuh gred tertinggi yang dipanggil kumpulan atasan. Kumpulan di bawahnya tidak dapat berpindah keatas kecuali ada perubahan organisasi atau karena keahlian yang dibutuhkan tetapi apabila pegawai yang bersangkutan dianggap ahli untuk suatu pekerjaan maka Malaysia juga memiliki mekanisme pinjam pakai pegawai dari satu instansi ke instansi lainnya yang membutuhkan tenaganya tersebut untuk kemudian kembali lagi pada posisi semula. Atau mengambil pegawai yang telah memasuki usia pensiun untuk diangkat sebagai pegawai sementara kembali tetapi bukan memperpanjang masa pensiun. Selain itu, yang mengurusi rekrutmen pengangkatan, penempatan, dan pengangkatan dalam jabatan serta pensiun itu hanya satu badan tersendiri dan bukan setiap kabupaten atau daerah mengurusnya. Dengan acuan yang sama serta penegakan disiplin kepegawaian yang tegas. Dengan demikian tidak akan dijumpai di Malaysia dan juga Sabah 
pegawai yang diangkat dengan kualifikasi teknik atau guru kemudian dimutasi menjadi pegawai pemerintah yang menduduki jabatan administrasi pemerintahan misalnya.

\section{Intervensi Pejabat Politik terhadap Pejabat Birokrasi}

\section{A. Rekrutmen}

Untuk menjadi Pegawai Negeri Sipil di Negara Bagian Sabah, harus melalui proses penyaringan yang ketat oleh suatu lembaga yang independen, yang disebut Suruhanjaya Perkhidmatan Awam Negeri Sabah (lihat bab IV) yang kedudukan lembaganya malah lebih tinggi dibandingkan dengan jabatan ketua menteri. ${ }^{10}$ Sehingga, akan sangat sulit apabila ada seorang pejabat menekan lembaga Suruhanjaya untuk memasukkan Pegawai Negeri Sipil. Intervensi untuk memasukan orang sebagai Pegawai Negeri hanya mungkin dilakukan oleh Ketua Menteri karena bagimanapun juga Ketua Menteri memiliki hak untuk mengusulkan pengangkatan dan pemberhentian anggota Suruhanjaya Perkhidmatan Awam Sabah kepada Yang di-Pertuan Negeri Sabah.

Sukarnya untuk mendorong seseorang menjadi birokrat di Sabah karena proses yang harus dilalui cukup panjang, diawali dari pengangkatan sebagai pegawai kontrak, selanjutnya diangkat sebagai pegawai tidak berpencen (tidak masuk daftar pensiun), atau percobaan. Untuk bisa menjadi pegawai berpencen, yang bersangkutan harus melewati masa percobaan minimal dua tahun, selanjutnya diuji kembali oleh Suruhanjaya Perkhidmatan Awam Negeri Sabah apakah yang bersangkutan dapat ditempatkan sebagai pejabat (jawatan berpencen) atau tidak. Untuk itu tersedia tes tertulis yang dibuat oleh Suruhanjaya, yang harus dikerjakan oleh pegawai yang bersangkutan. Waktu dan tingkat kesukaran soal yang dijawab tergantung pada skim (kelompok pegawai) yang akan dimasuki.

Pegawai Negeri di Malaysia juga dilarang berpolitik, tetapi diberi izin untuk menjadi anggota biasa suatu partai politik dengan syarat tidak boleh memperbincangkan masalah partai di kantor, memakai pakaian partai, serta

\footnotetext{
10 "Buku Profil Perkhidmatan Awam Negeri Sabah, Bagian Pembangunan dan Organisasi Jabatan Perkhidmatan Awam Negeri", Op. Cit., hal. 97.
} 
mengikuti berkampanye untuk suatu partai, dan memberikan pernyataan atau dukungan terbuka untuk suatu partai. ${ }^{11}$

\section{B. Penilaian Prestasi}

Untuk menilai prestasi seorang pegawai, Malaysia memiliki format lembaran (borang), yang diisi oleh setiap pegawai negeri yang dinilai leh dua orang atasan serta pegawai penyelaras gaji. Sehingga, apabila dinilai baik dan berprestasi, maka yang bersangkutan dapat dipertimbangkan kenaikan pangkat dan kenaikan gajinya. Borang (lembaran) sasaran kerja tahunan itu dikeluarkan setiap tahun dan memuat detail pertanyaan yang cukup banyak serta rasional dan logis. Untuk lebih jelasnya, contoh borang prestasi Sasaran Kerja Tahunan, peneliti lampirkan (lampiran 1). Penilaian prestasi dilakukan oleh Suruhanjaya Perkhidmatan Awam Sabah (SPANS). Pegawai awam yang dinilai juga harus mengisi borang penilaian prestasi tersebut dengan serius.

Penilaian juga dilakukan oleh pimpinan organisasi melalui record kerja pegawai yang kemudian diajukan kembali kepada SPANS. Penilaian untuk sebuah promosi ke jenjang pangkat yang lebih tinggi dan untuk menduduki jabatan birokrasi tertentu dibahas dalam sidang komisi SPANS atau JPA yang pada rapat pertama dihadiri oleh ketua jabatan dari pegawai yang akan dipromosi tersebut untuk menyampaikan catatan record kepegawaian yang bersangkutan sebagai masukan. Keputusan terakhir terletak pada sidang komisi SPANS yang hanya diahadiri oleh anggota JPA atau SPANS.

\section{Promosi Jabatan Birokrasi}

Sebagaimana yang telah dikemukakan dalam bab terdahulu, pengangkatan pegawai negeri dalam jabatan struktural di Negara Bagian Sabah dilakukan apabila jabatan yang hendak diisi tersebut disebabkan oleh pensiun atau berhentinya pejabat yang ada, atau adanya organisasi baru yang menuntut diadakannya pejabat baru untuk mengisi pos yang kosong tersebut. Pengangkatan juga atas usulan ketua jabatan kepada lembaga Suruhanjaya untuk kemudian diiklankan di koran. Setelah diiklankan maka para pegawai negeri yang merasa memiliki kualifikasi

\footnotetext{
${ }^{11}$ Lihat Pasal 21 Peraturan-peraturan Pegawai Awam, Kelakuan, dan Tata Tertib.
} 
sesuai sarat yang diiklankan dapat mendaftarkan diri kepada lembaga Suruhanjaya atau melalui pimpinan instansinya kemudian lembaga Suruhanjaya akan mengadakan seleksi. Siapa yang dinyatakan lolos maka dialah yang kemudian yang akan menempati pos jabatan tersebut. Pengangkatan tanpa iklan juga dapat dilakukan apabila lembaga Suruhanjaya memandang ada calon yang telah diusulkan oleh ketua jabatan dan mengingat jabatan yang hendak diisi tersebut bersifat segera dipenuhi dan teknis, sehingga apabila diiklankan akan memerlukan waktu yang lama.

Usulan ketua jabatan tersebut akan dibahas oleh lembaga Suruhanjaya untuk kemudian diplenokan oleh anggota lembaga Suruhanjaya apakah usulan ketua jabatan tersebut diterima atau ditolak. Untuk lebih membuat jabatan birokrasi didengarkan dan dihargai oleh para pejabat politik, maka untuk posisi Setiausaha Kementerian dan Ketua Jabatan Pelantikannya dilaksanakan oleh Yang di Pertuan Agong (Raja Malaysia) apabila di tingkat Persekutuan dan Raja atau Yang di-Pertuan Negeri untuk Setiausaha Negeri dan Ketua Jabatan di tingkat negara bagian. Kebijakan pejabat politik juga memiliki pengaruh yang signifikan dalam rekrutmen jabatan di Sabah.

Di Sabah dan Malaysia, pada umumnya akibat dari penyusunan pegawai yang meryt system, menyebabkan tidak mudah seorang pegawai memperoleh kenaikan pangkat. Sebab setiap jenjang kenaikan gred kepangkatan juga mengikut fasilitas berupa kesehatan, perumahan, kendaraan, liburan, serta fasilitas lainnya yang layak diperoleh sebagai seorang pegawai negeri dengan gred yang tinggi. Dengan demikian menonjobkan pegawai negeri merupakan kerugian bagi pemerintah.

Selain itu, campur tangan pejabat politik tidak terlalu nampak dalam pelaksanaan fungsi birokrasi kecuali birokrasi pada jabatan puncak, sebab disetiap kementerian terdapat Setiausaha Politik demikian juga pada setiap jabatan dan pejabat daerah. Setiausaha Politik tersebut berfungsi menjadi jembatan antara pejabat politik yang memimpin dengan aparat birokrasi yang berfungsi teknis. Sementara, di legislatif juga terdapat Setiausaha Politik parlemen yang fungsinya juga untuk menjembatani kepentingan pejabat politik yang ada di eksekutif dengan pembahasan yang dilakukan di legislatif. Intervensi pejabat politik seperti anggota Dewan Undangan Negeri, diakui oleh Anggota Dewan Undangan Negeri Sabah yang masih aktif hingga saat ini, Yang Berhormat Nilwan Caban Kaban bahwa anggota Dewan Undangan Negeri yang menang di suatu daerah tertentu berhak 
untuk mengajukan usul siapa pegawai daerah yang dapat diajak bekerjasama dengannya. Kerjasama tersebut dilakukan dalam bentuk menyukseskan implementasi kebijakan program-program pembangunan di daerah konstituen anggota Dewan Undangan Negeri tersebut.

Dalam hal pengawasan, memang diakui bahwa pegawai daerah adalah pegawai yang paling sering berurusan dengan pengurus partai politik, karena semua proyek pemerintah memang berada di daerah, sehingga para anggota parlemen juga menginginkan kepuasan bagi masyarakat yang menjadi pemilihnya.

\section{Faktor-Faktor yang Berpengaruh dalam Hubungan Pejabat Politik dan Pejabat Birokrasi di Sabah}

\section{A. Sistem Politik}

Sitem politik di Negara Bagian Sabah dan Malaysia pada umumnya memberikan kewenangan yang besar kepada lembaga eksekutif dalam penyelenggaraan dan kebijakan pemerintahan. Kondisi tersebut tercermin dari konstitusi Malaysia, yang menempatkan raja sebagai simbol saja, tetapi tidak memiliki kewenangan yang nyata. Kewenangan dalam pelantikan legislatif dan eksekutif juga merupakan kewenangan yang bersifat protokoler dalam arti walaupun dalam konstitusi Malaysia seorang raja dapat saja tidak melantik seorang perdana menteri, tetapi sepanjang prosesnya telah sesuai konstitusi, raja tinggal mengesahkan. Selain itu keberadaan politik Malaysia yang masih berpegang pada politik perkauman atau politik beradasarkan kesukuan menyebabkan demokrasi sulit untuk berkembang pada aras yang seharusnya.

Pemerintah yang berkuasa berlindung dibalik tameng keaslian dan ketuanan bagi kaum Melayu sehingga apapun yang dilakukan dalam kebijakan-kebijakan pemerintahan menjadi sulit untuk dikritisi, apalagi suku mayoritas kedua di Malaysia adalah Cina yang telah trauma pada saat terjadinya kerusuhan etnik 1964. Bahkan dalam kampanye pemilu tahun 2004, pemerintah Malaysia yang dipimpin oleh UMNO lewat Perdana Menteri Mahathir Muhammad mengemukakan bahwa berbahaya apabila Partai UMNO kalah, kejadian 1964 akan terulang di Malaysia. Kondisi tersebut jelas membuat luka traumatik kepada suku Cina dan suku lainnya yang non-Melayu yang ada di Malaysia. Kekhususan yang dan fasilitas yang juga diperoleh oleh kaum Melayu tersebut juga begitu mudah 
diselewengkan untuk kepentingan kaum Melayu khusus yang berada di partai atau kerabat penguasa. Terdapat contoh kasus usaha ke arah KKN di Malaysia. Misalnya adalah contoh yang akan dijelaskan berikut ini.

Malaysia juga memang memiliki lembaga-lembaga demokrasi sebagaimana trias politika lainnya yaitu legislatif dan yudikatif. Tetapi sebagaimana diuraikan dalam bab IV, Malaysia memilih perdana menteri di antara para anggota legislatifnya yang dengan demikian intervensi dan keinginan partai menjadi begitu lebih kuat untuk harus dilaksanakan, sehingga yang terpilih jadi perdana menteri tentulah pimpinan pusat dari partai yang berkuasa dan dominan di legislatif. Sebagai pimpinan partai yang berkuasa, maka yang bersangkutan tidak akan kesulitan untuk menghadapi legislatif. Memang ada anggota legislatif dari partai oposisi (partai pembangkang) seperti saat ini adalah Barisan Alternatif yang dipimpin oleh Anwar Ibrahim, tetapi upaya-upaya yang dilakukan oleh partai pembangkang atau oposisi tersebut tidak dapat bersuara mengingat adanya undang-undang yang memberikan pembatasan terhadap penerbitan berupa izin terbit hanya berlaku dua tahun sekali, setelah itu memohon kembali perpanjangan izin dari pemerintah. Sehingga, daripada dibreidel, maka pers memilih untuk tidak bersuara yang dapat melukai keinginan partai yang berkuasa. Apalagi sebagian besar saham pers juga dikuasai oleh orang-orang dalam lingkungan partai yang berkuasa.

Contoh terkini adalah larangan terbit dua kali seminggu menjadi dua kali seminggu bagi Harakah, tabloid milik partai oposisi yang dikeluarkan oleh Perdana Menteri Abdulah Ahmad Badawi. Alasan kebijakan tersebut menurut Badawi adalah hendak mempiawaikan penerbitan akbar ataupun majalah semua partai politik, agar memberikan peluang yang seksama bagi partai-partai politik yang lain ${ }^{12}$ karena Harakah dipandang berbahaya bagi pemerintah. Selain itu, kedudukan lembaga yudikatif juga tidak lepas dari kontrol eksekutif. Untuk kasus ini, dapat dikutip pernyataan Mahathir Muhammad Perdana Menteri Malaysia yang mempertahankan Hakim Agung Eusof Chin yang dituduh mengadakan kerjasama dengan jaksa penuntut dalam kasus Anwar Ibrahim:

Ketika dahulu kami bertindak memecat Ketua Hakim Negara (Tun Salleh Abbas) majelis penguamlah yang bangkit mengutuk

12 Kim Quek, 2006. Kemana Malaysia? Tampil Ke Reformasi Anwar atau Kekalkan Mahathirisme?. (Malaysia: SIRD, Petaling Jaya, 2006), hal. 170. 
kami. Sekarang mereka mahu seorang hakim yang memihak kepada mereka. Kalau anda boleh mengutuk saya karena memecat Salleh, saya juga boleh mengutuk anda karena cuba memecat Eusoff" (Quek, 2006:195).

Sementara, untuk independesi jaksa agung (Peguam Negara) jelas juga akan semakin merosot mengingat seperti halnya negara-negara lainnya, jaksa diangkat dan diberhentikan oleh pemimpin pemerintahan yang berkuasa. Kepolisian semakin tidak independen lagi, sebab kepala kepolisian juga berada langsung di bawah Perdana Menteri. Selain itu senjata pamungkas yang masih tetap dipertahankan oleh pemerintah Malaysia saat ini adalah Undang-undang ISA (internal security act) sebagaimana di Indonesia ada UU Subversif yang dulu diperuntukan bagi kaum komunis dalam masa pertentangan ideologi dunia antara liberalisme dan komunisme. Tetapi, di Malaysia, ISA masi tetap berlaku sebagai senjata terakhir penguasa untuk membungkam lawan-lawan politiknya yang berbahaya. Salah satu korban ISA adalah Anwar Ibrahim yang berbeda kebijakan dengan Perdana Menteri Mahathir Muhammad. Selanjutnya, para pemimpin muda Partai Kedaulatan yang didirikan oleh Istri Anwar Ibrahim dan mereka yang ditahan dilarang mengikuti pemilu yang menyebabkan tidak maksimalnya suara Partai Kedaulatan dalam Pemilu 2004.

Kekuatan Partai UMNO bisa tetap bertahan dalam kondisi hingga hari ini, karena ditopang oleh sistem politik perkauman (kesukuan) yang dilembagakan secara implisit dalam konstitusi Malaysia. Selain itu kondisi kesejahteraan Malaysia yang masih memungkinkan terpenuhinya kebutuhan pokok masyarakatnya menyebabkan kemarahan rakyat untuk melawan politik diskriminasi rasial dan KKN dalam pemerintahan tidak menguat dan mengemuka. Bilamana terjadinya krisis ekonomi yang dapat membawa pada menurunya kualitas kehidupan masyarakat, hal itu akan menjadi bencana bagi pemerintahan Malaysia yang ditopang oleh UMNO saat ini. Secara umum sistem politik Malaysia saat ini sama halnya dengan model sistem politik Indonesia sebelum reformasi. Kekuasaan terpusat pada eksekutif, tetapi kadar KKN yang terjadi di Indonesia lebih parah dibanding Malaysia hari ini karena beberapa alasan, tetapi yang mendasar menurut hemat peneliti adalah $\mathrm{KKN}$ terjadi pada seputaran kaum Melayu saja yang ada dalam partai yang berkuasa sehingga biasanya tidak mengemuka dan menjalar luas sebagai isu politik yang berbahaya karena 
pemerintah selalu memelihara isu perkauman seperti larangan berpolitik di kampus semacam model Normalisasi Kehidupan Kampus di jaman Orde Baru di Indonesia, padahal untuk masuk diperguruan tinggi di Malaysia juga dibatasi oleh kuota 60\% untuk calon mahasiswa Melayu dan 40\% untuk mahasiswa non-Melayu demikian pula yang hendak bersekolah keluar negeri juga dikenakan pembatasan yang demikian.

Seterusnya, sampai pada pembatasan berusaha dalam setiap perusahaan yang didirikan oleh kaum non-Melayu, wajib menyertakan minimal 10\% saham untuk kaum Melayu. Menurut Arif Akmal Ayub, wujud dari masuknya saham untuk orang Melayu tersebut diberikan dalam bentuk pemilik perusahaan, bukan warga Melayu tersebut mencari orang Melayu yang dianggap berpengalaman dan berpengaruh yang biasanya mantan petinggi birokrasi dan partai yang selanjutnya tugas dari orang Melayu tersebut lebih hanya sebagai backing dan penasehat untuk masuk dalam proyek-proyek pemerintah atau usaha yang berhubungan dengan pemerintah. Di Indonesia, pada masa lalu pratek yang demikian lazim diberikan pada para mantan pejabat tinggi atau perwira militer pensiunan untuk menjadi komisaris dan lain-lain dalam sebuah perusahaan demi sebuah pengamanan dari usaha tersebut.

\section{B. Budaya Politik Birokrasi}

Malaysia, khususnya Negara Bagian Sabah, dalam pengaturan manajemen kepegawaiannya banyak tertolong oleh sistem kepegawaian yang dibangun oleh Inggris pada masa penjajahannya. Selain itu, apabila mempelajari perkembangan sejarah pemerintahan Sabah, terutama pada masa sebelum kolonialisme, maka dapat dikatakan bahwa di Sabah tidak memiliki budaya birokrasi tersendiri mengingat tidak adanya satu kerajaan kuat yang pernah berdiri di daerah tersebut. Sehingga, pada periode penjajahan Sabah, Inggris dapat menerapkan sistem birokrasi seperti yang ada di negara asalnya, tanpa mengalami kesulitan. Oleh karena itu apabila membaca peraturan perundangan kepegawaian Malaysia, hampir semua peraturan kepegawaian merupakan peratutan yang diubah dari peraturanperaturan lama sejak tahun 1957 atau 1958. Dengan demikian, dapat disimpulkan bahwa setelah menasionalisasi semua peraturan pemerintahan Inggris, pada masa awal kemerdekaannya. Malaysia rata-rata baru mengadakan sekali perubahan dalam peraturan kepegawaiannya. Kesadaran untuk mengadakan penyesuaian ini muncul di Malaysia sejak 
tahun 1960-an, untuk lebih jelasnya berikut pernyataan Tuanku Abdul Aziz, mantan Perdana Menteri Malaysia yang berhasil membawa Malaysia keluar dari krisis sosial terbesar antara etnis Cina dan Melayu di tahun 1969 ${ }^{13}$ (Ahmad, 1994:126).

Salah satu hasil dari suatu upaya reformasi dalam sistem pemerintahan tersebut, di antaranya adalah perubahan dalam sistem pelatihan kepegawaian yang dilaksanakan oleh jabatan Perkhidmatan Awam serta upaya untuk mengadakan swastanisasi terhadap aset-aset publik yang dimiliki oleh pemerintah baik pusat maupun di daerah. Untuk lebih memahami perkembangan reformsI sistem pemerintahan di Malaysia, dapat membaca buku Perkembangan Pentadbiran Awam dan Pengurusan oleh Abdulan Sanusi Ahmad.

\section{Jabatan Perkhidmatan Awam Malaysia (JPA)}

Pengaturan kepegawaian di Negara Bagian Sabah Malaysia mengacu pada konstitusi Negara Malaysia. Pengaturan tentang kepegawaian diatur dalam Bab X konstitusi federal Malaysia, yang di dalamnya menyangkut semua pelayanan umum yang wajib dilaksanakan oleh negara. Kewenangan di bidang kepegawaian (public service) diatur dalam pasal 132 konstitusi Malaysia tentang keberadaan "the general public service of the Federation". Dalam pelaksanaannya, pembinaan birokrasi (civil service) dilasanakan oleh lembaga Jabatan Perkhidmatan Awam (JPA). Yang terbagi atas jabatan Perkhidmatan Awam Negara Malaysia dan jabatan Perkhidmatan Awam khusus di negara bagian Sabah, sebagaimana diatur dalam pasal 132 kontitusi Malaysia sebagai salah satu kewenangan pangkal Negara Bagian Sabah yang bergabung dalam federasi Malaysia.

Jabatan Perkhidmatan Awam Malaysia, merupakan lembaga negara yang bertangungjawab dalam pembinaan sumber daya manusia sektor umum (birokrasi) yang melaksanakan tiga tugas utama yaitu:

i. Menetapkan standar penyelenggaraan kepegawaian dan memantau pelaksanaannya dilapangan;

ii. Memberikan nasehat, petunjuk dan masukan kepada instansi terkait yang memperkerjakan pegawai negeri;

${ }^{13}$ Abdulah Sanusi Ahmad, "Perkembangan Pentadbiran Awam dan Pengurusan", (Kuala Lumpur: Dewan Bahasa dan Pustaka, 1994), hal. 126. 
iii. Melaksanakan aturan yang telah diputuskan dalam bidang pelayanan pemerintahan, pelayanan bimbingan dan pembinaan, pelatihan dan pensiun.

Ketiga tanggungjawab tersebut selanjutnya dijabarkan dalam bentuk pembagian program kerja, yang dapat dilihat dalam bagan berikut:

Gambar 2.

\section{Struktur Organisasi Jabatan Perkhidmatan Awam}

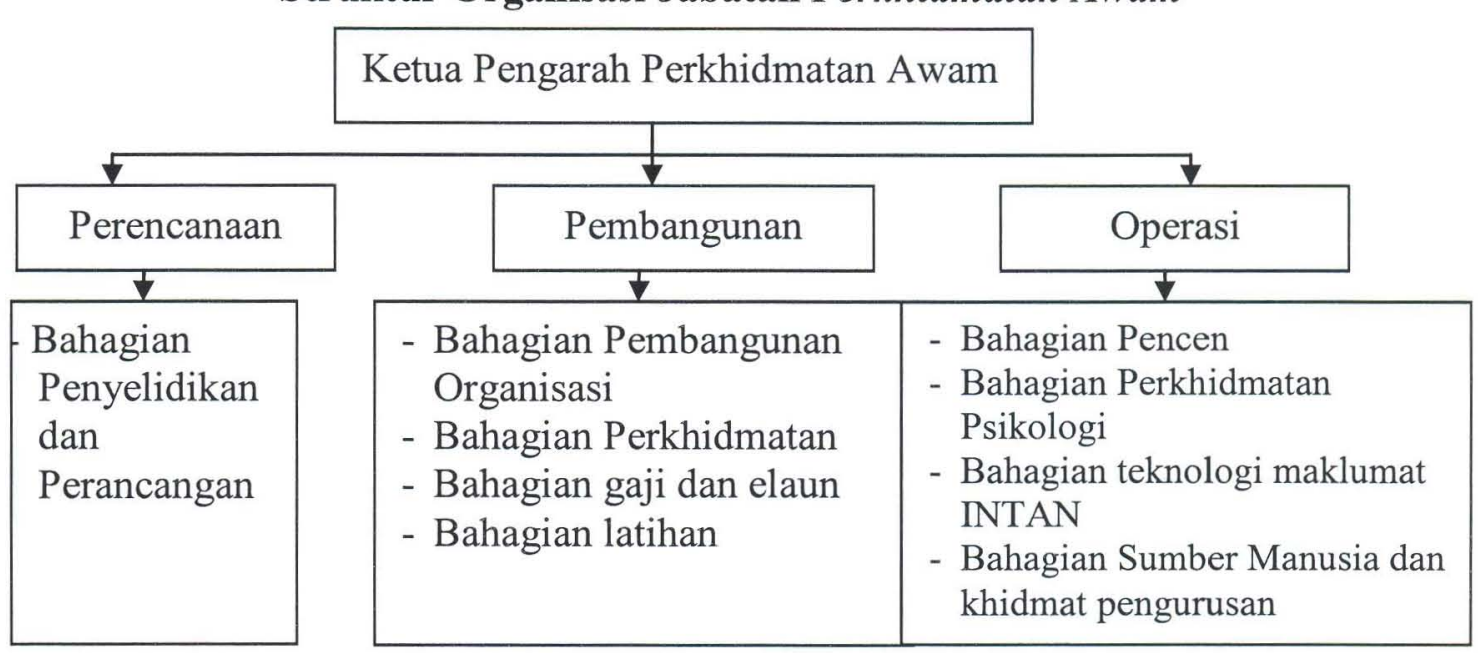

Sumber: Situs resmi kerajaan Sabah(2008).

\section{Suruhanjaya Perkhidmatan Awam Negeri Sabah}

Lembaga ini merupakan perwujudan dari Lembaga Suruhanjaya Perkhidmatan Awam pada pemerintah pusat. Sabah dan Serawak merupakan dua negara bagian yang memiliki Lembaga Suruhanjaya Perkhidmatan Awam sendiri. Tetapi secara umum apa yang menjadi tanggungjawab dari lembaga Suruhanjaya di tingkat persekutuan juga merupakan tugas dari lembaga Suruhanjaya di tingkat negara bagian, termasuk Sabah. Demikian pula halnya dengan perturan perundangan yang dibuat juga merupakan yang berlaku sama. Dalam aturan pensiun menurut Undang-undang Pensiun terbaru di Malaysia, para pegawai dapat pensiun pada umur 56 tahun, tetapi dengan Perkeling Perkhidmatan Bilangan 6 Tahun 2008 tentang Tawaran Opsen Wajib kepada 58 tahun, maka 
pegawai diberi kesempatan untuk memilih tetap kepada pensiun 56 tahun atau beralih kepada pensiun 58 tahun sesuai aturan baru yang mulai berlaku tanggal 1 Juli 2008.

Di Negara Bagian Sabah, Suruhanjaya Perkhidmatan Awam yang disingkat SPANS merupakan kelanjutan dari lembaga yang sama fungsinya di jaman penjajahan Inggris yang disebut The North Borneo (Public Service Commision) Order in Council, yang dalam perlembagaan Negeri Sabah setelah Kemerdekaan diatur dalam pasal 36 (1). Tujuan dari lembaga ini adalah untuk memastikan urusan rekrutmen (penerimaan), pelantikan (pengangkatan), perkhidmatan (pelayanan), dan tindakan tata tertib pegawai birokrasi dilaksanakan dengan adil, seksama, tepat, cepat dan efisien.

\section{E. Rekrutmen Birokrasi}

Mengacu pada aturan perundangan di Malaysia, maka rekrutmen pegawai negeri sipil diawali dari pengangkatan sebagai pegawai kontrak, selanjutnya pegawai sementara atau pegawai tidak berpencen (pensiun), selanjutnya pegawai berpensiun. Seseorang yang dinyatakan lulus sebagai pegawai kontrak dalam satu seleksi yang diadakan oleh suatu instansi (jabatan) pemerintahan (pentadbiran awam) sesuai perjanjian dan kebutuhan kantor pemerintah, setelah itu baru kemudian dapat dipertimbangkan untuk mengikuti seleksi pegawai tetap dan berpensiun. Itupun apabila yang bersangkutan mendapatkan penilaian kerja yang baik. Apabila tidak, maka yang bersangkutan tidak dapat mengikuti seleksi. Bahkan pegawai kontrak tersebut tidak dapat lagi melanjutkan masa kontraknya.

Pengangkatan pegawai kontrak dilakukan oleh jabatan perkidmatan awam negeri sabah atas usulan dari pejabat yang memimpin sebuah instansi atau jabatan. Demikian pula perpanjangan masa kontrak bagi pegawai kontrak; pegawai kontrak yang bersangkutan apabila berkeinginan untuk memperpanjang kontraknya, maka pegawai kontrak tersebut harus menyampaikan keinginannya kepada ketua pejabat pada jabatan (instansi) tempatnya bekerja. Jika ketua jabatan menghendaki maka ketua jabatan mengusulkan kepada Suruhanjaya Perkhidmatan Awam Negeri Sabah. Beserta alasan mengapa masih diperpanjang kontraknya. Sekiranya ada syarat-syarat baru yang hendak ditambahkan pada posisi pegawai kontrak dimaksud, maka syarat tambahan tersebut disampaikan kepada 
Suruhanjaya Perkhidmatan Awam, sesuai dengan syarat-syarat yang telah disetujui oleh ketua pengarah Perkhidmatan Awam. Persetujuan diperpanjang tidaknya menjadi kewenangan dari Suruhanjaya Perkhidmatan Awam.

\section{F. Jenis-jenis Pengangkatan Pegawai}

\section{i. Pelantikan/pengangkatan pegawai sementara}

Calon-calon pegawai yang telah dinyatakan lulus akan diangkat sebagai pegawai sementara. Pengangkatan pegawai sementara dilaksanakan untuk alasan memudahkan suatu pekerjaan yang mendesak, membuat proses seleksi dan pengangkatan lebih cepat, dan memudahkan pemerintah menggaji orang yang mempunyai bakat, kemahiran/ keahlian, dan pengalaman khusus apabila diperlukan.

\section{ii. Pengangkatan Pegawai Kontrak}

Pengangkatan pegawai kontrak dilaksanakan karena alasan mengatasi masalah kekurangan pakar bidang tertentu, menjalankan suatu tugas tertentu untuk suatu tempo masa yang ditentukan, memenuhi syarat perkhidmatan mandatori seperti yang ditentukan pemerintah, dan membolehkan penggajian orang yang mempunyai pengalaman, kemahiran, dan bakat yang diperlukan tetapi tidak dapat memenuhi syarat perkhidmatan berkaitan dengan kewarganegaraan atau bahasa kebangsaan, seperti yang ditetapkan oleh skim perkhidmatan yang berkaitan. Pegawai kontrak bisa diisi oleh warga negara asing, atau oleh para pensiunan pegawai negeri yang keahliannya masih diperlukan. Kontrak dilaksanakan untuk waktu maksimal tiga tahun tetapi bisa diperpanjang untuk yang kedua kalinya selama masa dua tahun, setelah itu dapat pula diperpanjang selama waktu satu tahun. Jumlah masa kontrak berikut perpanjangannya tidak boleh melebihi enam tahun. Untuk pegawai kontrak asing masa kontrak awal adalah minimal satu tahun. Dan tidak boleh melebihi masa kontrak lebih dari sepuluh tahun.

iii. Pengangkatan Pegawai Sambilan

Pengangkatan pegawai sambilan dilaksanakan untuk memenuhi keperluan kerja jangka pendek seperti pertambahan beban kerja, yang tidak diprogramkan. Pegawai sambilan diangkat untuk waktu maksimal 
enam bulan, atau lebih pendek lagi. Mereka tidak dikenakan aturan dasar kepegawaian sebagiamana yang dikenankan kepada pegawai tetap, kontrak atau sementara.

iv. Pengangkatan untuk Orang Cacat Fisik

Dalam pengangkatan pegawai di Malaysia, diwajibkan satu persen dari seluruh karyawan adalah penyandang cacat fisik yang relevan keilmuannya dan keahliannya dengan pekerjaan yang diberikan. Hal ini dimaksudkan agar penyandang cacat fisik juga dapat memiliki kesempatan untuk memasuki pasar kerja.

\section{G. Pembagian Jenis Pegawai Negeri}

Secara umum, Malaysia membagi struktur kepangkatan pegawainnya dalam empat bahagian, yang terdiri atas:

i. Bahagian pertama : pegawai pentadbir dan profesional, atau

ii. Bahagian kedua : eksekutif dan teknikal atau kumpulan separuh ikhtisas dan profesional;

iii. Bahagian ketiga : kumpulan perkeranian dan teknik;

iv. Bahagian keempat : kumpulan buruh umum

\section{Penutup}

Model hubungan pejabat politik dan pejabat birokrasi serta ciri hubungan pejabat politik dan pejabat birokrasi di Sabah adalah:

1. Regulasi tentang manajemen birokrasi diatur dalam salah satu pasal Konstitusi Negara (perlembagaan Persekutuan Malaysia, pasal 132) serta dalam perlembagaan Negara Bagian Sabah yang selanjutnya diturunkan dalam bentuk regulasi yang dibuat oleh eksekutif politik dan parlemen;

2. Manajemen selanjutnya menyangkut rekrutmen birokrasi, karier dan pensiun, serta penilaian prestasi dikendalikan oleh Lembaga Suruhanjaya Perkhidmatan Awam (Persekutuan/Sabah) yang keberadaannya diatur dalam Konstitusi; 
3. Dalam pemerintahan terdapat pejabat politik yang diangkat atas dukungan parlemen dari partai pemenang pemilu, serta dibantu oleh Setiausaha Politik dan Setiausaha Parlemen yang diangkat oleh para menteri. Serta terdapat setiausaha negeri dan kementerian serta ketua jabatan yang merupakan pejabat birokrasi karier, yang diusulkan oleh Suruhanjaya Perkhidmatan Awam yang kemudian dipilih dan dilantik oleh Yang diPertuan Agong bagi Pusat, dan Yang di-Pertuan Negeri bagi Sabah;

4. Birokrasi harus netral terhadap kegiatan politik praktis kecuali pegawai negeri pada kumpulan kepangkatan menegah ke bawah dapat menjadi simpatisan partai tetapi tidak boleh membicaran partai di kantor.

Berdasarkan pada ciri tersebut di atas, sangat jelas bahwa Sabah mengikut atau sejalan dengan model Bureaucratic Sublation dari Carino, atau model Rilling Bureaucratic dari Marle Fainsod. Model hubungan ini dapat terjadi karena adanya kerangka hukum yang tegas mengatur manajemen birokrasi. Keberadaan Lembaga Suruhanjaya Perkhidmatan Awam yang merupakan komisi kepegawaian yang independen yang anggotanya juga dipilih dari orang-orang yang profesional tidak boleh dari partai politik, dan juga tidak dibenarkan berasal dari kalangan pegawai negeri sipil. Hal tersebut menyebabkan kedudukan komisi kepegawaian dapat lebih independen dan berdaya bila berhadapan dengan pejabat politik. Selain itu faktor kepatuhan terhadap hukum dan warisan budaya birokrasi dari penjajah Inggris menyebabkan Sabah memiliki karakter hubungan pejabat politik dan pejabat birokrasi seperti yang disebutkan di atas. 


\section{Daftar Pustaka}

Abudullah, Hamzah Shalt. Pentadbiran Kewangan Kerajaan Tempatan di Semenanjung Malaysia, Malaysia: Dewan Bahasa dan Pustaka Kementerian Pendidikan Malaysia, 1992.

Ahan, Byong Man. Elite and Political Intervention in South Korea, Chatelham: Edward Elgar Publishing, tanpa tahun.

Ahmad, Abdulah Sanusi. Perkembangan Pentadbiran Awam dan Pengurusan, Kuala Lumpur: Dewan Bahasa dan Pustaka, 1994.

Ali, Abdul Halim (Ed.). et.al. Sabah dalam Perluasan Pasaran, Malaysia: Universitas Kebangsaan Malaysia, 2000.

Bealeghole, J.H. The Distric a Study In Decentralization in West Malaysia, London: Oxford University Press, 1976.

Burgess, John W. Comparative Study of The Structure Of The Legislative Departement, Published By Ginn and Company, 1981.

Crook Richard C, and James Manor, Democracy and Desentralisation in South Asia and West Africa, Participation, Acountability and Performance, Jurnal Comparative Public Administration, (copy 2009).

Hamza, Muhammad dan Hamat, Noor Zari. Enchanging National Competitiveness Through Efective Implementation, Kuala Lumpur: Intan, 2007. tanpa tahun.

Harding, Andrew. Law, Government and the Constution in Malaysia, Kuala Lumpur: Malayan Law Journal Sdn Bhd, 1996.

Hussain, Ahmad Atory. Pengantar Pentadbiran Awam Paradigma Baru, Kuala lumpur: Utusan Publication \& Distributors Sdn BHD, 2004.

Ibrahim, Ahmad. Sejarah UU di Malaysia dan Singapura, Kuala Lumpur: Dewan Bahasa dan Pustaka, 1995.

Ismail. Hubungan Pemimpin Politik dan Birokrasi, Kuala Lumpur: Disertasi pada Fakultas Ekonomi dan Pentadbiran, Malaya University. 1992.

Jawam, Jayuma. Malaysia Politics and Government, Selangor: Karisma Publication Sdn Bhd, Sha Alam Selanggor, 2007. 
Lee, Maria Othman. Kementerian dan Jabatan, Kinabalu, 1992.

Ali, Mazlan Bin. Hubungan Semangat 46 dan PAS 1988-1996 Satu Tinjauan Politik Terhadap Politik Malaysia, Disertasi Fakultas Ekonomi dan Pentadbiran Universty Malaya, Kuala Lumpur, 1998.

Mohamud, Syed Shahir. Pekerja Malaysia Terpinggir di Bumi Kaya. Malaysia, 2006.

Quek, Kim. Kemana Malaysia? Tampil Ke Reformasi Anwar atau Kekalkan Mahathirisme?, Malaysia: SIRD, Petaling Jaya, 2006.

Saat, Gusni. Komuniti Sama-Bajau di Bandar, DKM Bangi Malaysia, 2003.

Sabitha, Marican. Dasar Awam di Malaysia Isu dan Konsep, Selangor: Utusan Publications \& Distributors SDN BHD, 1997.

Said, Fuad. Ketatanegaraan Menurut Syariat Islam, Kuala Lumpur: Dewan Bahasa dan Pustaka, 2002.

Sanit, Arbi. Sistem Politik Indonesia, Jakarta: Rajawali Press, 1981.

Sarji. Perkhidmatan Awam Menuju Era Baru, Kuala Lumpur: Intan, 1996.

Smith, Judy Gregory. South Sulawesi Islands of Surprise, Departemen of Tourism, Art and Cultural Southeast Sulawesi Regional Office, Kendari, 2000.

Smith, BC. Bureucracy and Political Power, Sussex: Wheatsheaf Books, 1988.

Smith, Thomas B. The Comparative Analiysis Of Bureucratic Acountability, Asian Journal of Public Administration, Vol. 13, Juni 1991 (93-108).

Tajudin, Hasi Hussain. Malaysia Negara Kita. Kuala Lumpur: MDC. Publishers Sdn Bhd, 2000.

Perkembangan dan Undang-Undang Am. Buku Panduan Perperiksaan Am, Kuala Lumpur: Kenyas, MDC, Publishers SDN Bhd, 2009.

Way, Yew Chee. Target PMR Sejarah, Petaling Jaya: Sasbadi Sdn Bhd, 2002.

Wong, AH Lee. 1998. Pentadbiran dan Peranan Majelis Daerah Lipis dalam Pembangunan Tempatan, Disertasi Fakultas Ekonomi dan Pentadbiran, University Malaya Kuala Lumpur, 1998. 


\section{Buku-buku Terbitan Pemerintah}

Buku Profil Perkhidmatan Awam Negeri Sabah, Bagian Pembangunan dan Organisasi Jabatan Perkhidmatan Awam Negeri. 1995. Kinabalu.

Laporan Penelitian Reformasi Birokrasi Publik di Indonesia. 2001. Pusat Studi Kependudukan dan Kebijakan UGM.

Pentadbiran dan Pengurusan Awam Malaysia. 2006. Kuala Lumpur: INTAN.

Perkeliling Kemajuan Pentadbiran Awam dan Profil Perkhidmatan Awam Malaysia, Cetakan ke-16, 2008. Kuala Lumpur: MDC Publishers Sdn Bhd.

Malaysia Kita. 1994.Kuala Lumpur: Istitut Tabiran Awam Negara (INTAN).

Malaysia Kita. 2007.Kuala Lumpur: Istitut Tabiran Awam Negara (INTAN).

Pentadbiran dan Pengurusan Awam Malaysia. 2006. Kuala Lumpur: INTAN.

Panduan Undang-Undang Umum Malaysia Hingga Agustus 2008. Kuala Lumpur: International Law Book Service. 